\title{
Production Scenario and Marketing Constraints for Small Holding Vegetable Farmers: Evidence from Sindupalchowk District, Nepal
}

\section{Manoj Sharma*}

Department of Agricultural Economics and Agribusiness Management, Agriculture and Forestry University, Chitwan, Nepal

*Corresponding Author: Manoj Sharma, Department of Agricultural Economics and Agribusiness Management, Agriculture and Forestry University, Chitwan, Nepal.

Received: May 13, 2019; Published: June 18, 2019

DOI: 10.31080 /ASAG.2019.03.0533

\section{Abstract}

The study is conducted in Sindupalchowk district of Nepal with the objectives of finding the production scenario and marketing constraints for small holding vegetable farmers. A purposive sample of 84 small holding vegetable farmers were selected for survey and interviewed with semi-structured questionnaire. The data collected were analyzed by use of Excel and SPSS software. The results showed that the role of government to production of vegetable by small holding farmers were not such significant than that of other agencies like NGOs, mass media and other private sectors. The education, age and land size are found to be significant to increase the marketable surplus of vegetables. The study result also showed that vegetable producers were faced with lack of input supply and poor mechanization. On marketing side, lack of storage facility, poor market access, lack of transportation, low price of output and inadequate government support for price determination are the major problems. Therefore, policy implications drawn from the study findings included the need to price determination, improving the input supply system, improving the farmers' technical knowledge on vegetable production, strengthening the linkage between value chain actors and increasing the efficient extension system.

Keywords: Constraints; Likert Scale; Marketable Surplus; Regression; Vegetable

\section{Introduction}

Vegetable production is one of major potential crop contributing to uplift of socio-economic status of small landholding farmers in Nepal. It has capacity to return more from per unit land as compared to other cereal crops [1]. The vegetable sector in Nepal has grown rapidly over the last 10 years, primarily through producers diversifying away from staple crops (rice, maize etc.), and have surpasses benefit cost ratio and commercialization rate [2]. So, vegetable crops can provide ample opportunities of income generation including the women farmers and enhancing their accessibility to food security because vegetable crops provide 5-10 times more yield per unit area as compared to cereal crops and subsequently give high return [3].

Large numbers of Nepalese farmers have small holdings and are specialized to vegetable farming [4]. But the increasing demand situation of vegetables is not being able to match. The main reason behind are production and marketing constraints [5]. Therefore, different constraints of market oriented production and market operation for vegetable crops need to be identified precisely to improve smallholder farm economy. Unless the associated problems are identified and abated, alleviating poverty in the farming communities as envisaged by national development goal would not be possible. Real problems in the system can only be described, when the economy of production mechanism and marketing system for major vegetable products operating in a particular area is evaluated.

Vegetable production is considered as high value crop in the context of Nepal and is one of the gradually emerging sub-sectors as contributing to GDP. On other hand, Sindupalchowk is a hillydistrict with substantial number of small land holding farmers with limited resources and human skills [6]. Thus, the research has studied on production scenario and marketing performance analysis to know the constraints of vegetable production from input supply to consumer within this district. This study also provides information on the determinants of vegetables supply to the market and identifies opportunities and constraints of vegetables production and marketing in the study areas. So, this study helps to way forward 
for information and suggestions to concerned agencies for increasing per capita income of small holding farmers of Sindupalchowk district.

\section{Methodology}

The study was based on intensive field survey. Total six VDCs of Sindupalchowk district were purposively selected. The lists of vegetable farmers were collected from District Agricultural Development Office (DADO) and 84 sample household lists of vegetable farmers were selected on the basis of proportional to total vegetable farmers of those VDCs. The semi-structured questionnaires were administered to conduct household survey. Through household survey, the socio-economic characteristics of vegetable farmers and other relevant information such as source of information, major markets and vegetable use patterns were collected. The analytical procedures used during the study are given below;

\section{Descriptive analysis}

The frequency distribution, percentage distribution, means, graphs, pie charts were used to represent the various characteristics of production and marketing aspects of vegetables.

\section{Problem analysis}

The problems regarding the vegetable production and marketing system were collected by use of five point likert scale. The rating of problems as provided by likert scale was analyzed and ranked by determining their state of importance. The value of most severe, severe, moderate, slightly and no problem are given as $1,4 / 5,3 / 5$, $2 / 5$ and $1 / 5$ respectively.

State of importance $=\sum_{1}^{5} f i \times x i / N$

Where, $\mathrm{f}_{\mathrm{i}}=$ frequency of $\mathrm{i}^{\text {th }}$ scale, $\mathrm{x}_{\mathrm{i}}=$ value for $\mathrm{i}^{\text {th }}$ scale and $\mathrm{N}=$ total number of sample size.

\section{Determinants of market supply: Use of multiple regression}

Vegetable marketed surplus, in a form of independent variable, is determined by various socio-economic dynamics of farmers. Thus, to determine the market supply of vegetable, Giziew [7] has used multiple linear regression model in his study which is given as,

$$
Y_{i}=\beta_{1}+\beta_{2} X_{2 i}+\ldots \ldots \ldots \ldots+\beta_{k} X_{K i}+u_{i}
$$

Where, $Y_{i}=$ marketed surplus of vegetable, $X_{i}=$ vector of explanatory variables, $\beta_{i}=$ vector of parameters to be estimated, and $u_{i}=$ the regression residual (error)

\section{Results and Discussion}

Socio-demographic characteristics of farmers

The survey result showed that the average age of sampled household was 45 years with minimum and maximum age of 24 and 90 respectively. This implies that many of respondents in the survey area were mature people who could be actively engaged in vegetable production and marketing to generate sufficient income to run their lives as well as their families. Only eight households $(9.52 \%)$ were female headed household while, $90.48 \%$ were male headed households. The survey result also showed that $35.71 \%$ of sampled household heads were illiterate. However, $32.14 \%$ and $30.95 \%$ attended primary and secondary school respectively whereas, $1.19 \%$ attended college and above. The family sizes of two to twelve were witnessed in the study area and the average household family size was found to be 5.60. This means household members might provide the major source of labors for vegetable production. The majority of households were Janajati, especially Tamang representing $48.81 \%$ of sampled households. However, $29.76 \%$ and $21.43 \%$ were Chhetry and Brahmin respectively. About 58 percent of household heads were found to have membership of cooperatives.

\begin{tabular}{|c|c|c|c|}
\hline \multirow[t]{2}{*}{ Variables } & \multirow[t]{2}{*}{ Indicators } & \multicolumn{2}{|c|}{$\begin{array}{l}\text { Vegetables producers } \\
\qquad(\mathrm{N}=84)\end{array}$} \\
\hline & & Frequency & Percentage (\%) \\
\hline $\begin{array}{l}\text { Age of } \\
\text { households }\end{array}$ & $\begin{array}{c}\text { Mean } 45.52 \\
(14.04)\end{array}$ & & \\
\hline \multirow{2}{*}{$\begin{array}{l}\text { Gender of } \\
\text { household }\end{array}$} & Male & 76 & 90.48 \\
\hline & Female & 8 & 9.52 \\
\hline \multirow[t]{4}{*}{ Education } & Illiterate & 30 & 35.71 \\
\hline & $\begin{array}{l}\text { Primary } \\
\text { education }\end{array}$ & 27 & 32.14 \\
\hline & $\begin{array}{l}\text { Secondary } \\
\text { education }\end{array}$ & 26 & 30.95 \\
\hline & $\begin{array}{l}\text { College and } \\
\text { above }\end{array}$ & 1 & 1.19 \\
\hline \multirow{2}{*}{$\begin{array}{l}\text { Cooperative } \\
\text { memberships }\end{array}$} & Yes & 58 & 69.05 \\
\hline & No & 26 & 30.95 \\
\hline \multirow[t]{4}{*}{ Ethnicity } & Bhramin & 18 & 21.43 \\
\hline & Chhetry & 25 & 29.76 \\
\hline & Janajati & 41 & 48.81 \\
\hline & Others & 0 & 0.00 \\
\hline Family size & $\begin{array}{l}\text { Mean } 5.60 \\
\quad(2.01)\end{array}$ & & \\
\hline
\end{tabular}

Table 1: Demographic and socioeconomic characteristics of study area.

Note: Standard deviation in parenthesis

Source: Household Survey, 2016 
Vegetables supply to markets

The study reveals that markets are comparatively at close distant as many of household sell their product at local market with average of $42.38 \%$ which in turn may assist farmers to lessen their transport cost and enhances their market surplus and margins. Farmers often prefer to sell on the spot or at local market due to perishability of vegetable and lack of capacity to sell at bigger markets far from their residence. In addition, accessibility of roads capital city Kathmandu makes easier for traders to enter small trucks to production site which also accounts for $18.97 \%$. It is usually highlighted that closer markets do promote farmers to plant high value vegetables in view of the fact that they are not forced to transport their produce to distant markets where they incurs extra cost and might sell it at loss. Thus, the place of sell could diminish transport cost and enhance their market surplus considerably.

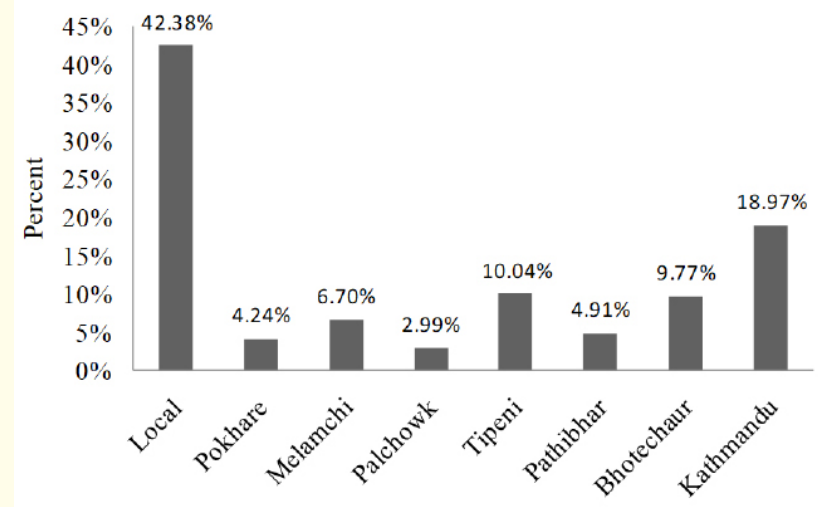

Figure 1: Vegetable supply to market centers. Source: Household Survey, 2016.

Involvement of different sectors for production and marketing of vegetables

The involvement of different sectors means to help for providing technical knowledge, market information and others facilities for training and price determination. In study area, major involved agencies were found as government extension staff, NGOs/INGOs, other farmers, mass media, print media, own experience, agro dealers, neighbors / relatives and internet. Figure shows that with average of $19.30 \%$ were not supported by others and fully self involved, and then followed by NGOs and other farmer each of $19.10 \%$ contribution for production and marketing. Internet was of least important source of information $(0.2 \%)$ in study area. However, it is expected to increase in upcoming year due to technological prog- ress. The graph is made from the multiple response of farmers responded to involvement of different agencies and sectors.

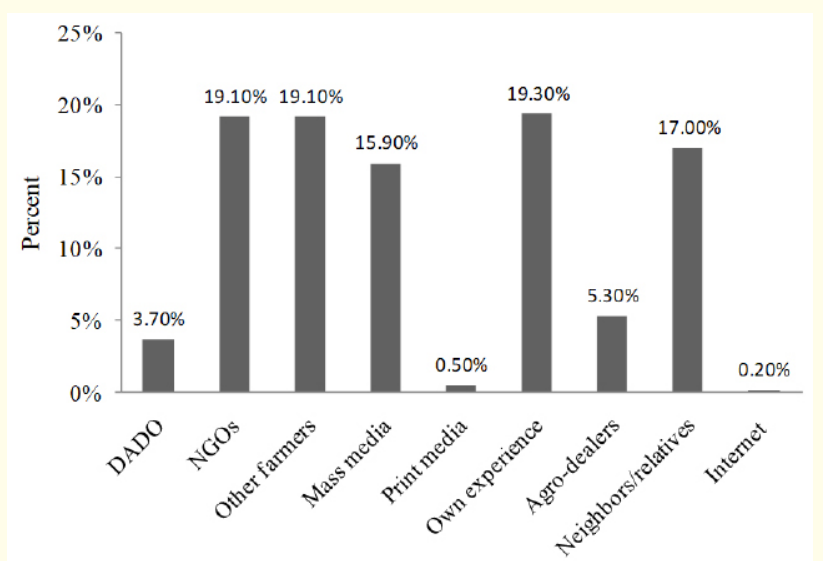

Figure 2: Involvement of different sectors on vegetable production and marketings.

Source: Household Survey, 2016

\section{Vegetable use pattern of households}

The vegetable use pattern of households is mainly depends upon type of producers based on farming scale. In the study area, around $60 \%$ of total produced vegetable was found to be sold by sampled households. It means they were semi-commercialized farmers. However, significant amount of vegetable (5\%) was found to be lost as wastage. The main reason behind this loss is due to lack of storage facility. Some other reasons were post harvest pest and diseases, poor marketing facility and lack of transportation. The detail of use pattern is shown in pie chart.

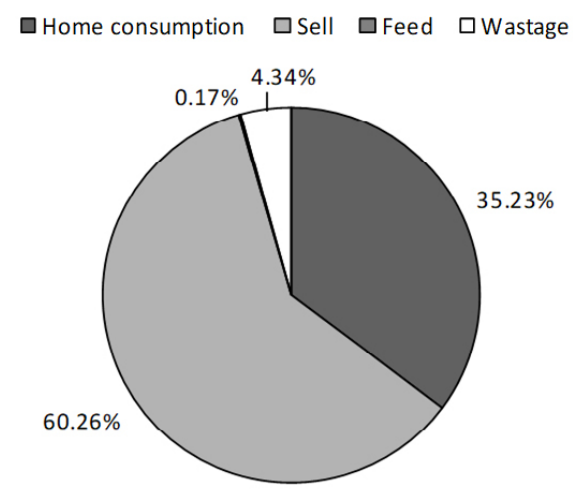

Figure 3: Vegetable use pattern.

Source: Household Survey, 2016 
Determinants of vegetable supply

Multiple regressions were conducted to examine the relationship between amount of vegetable marketed and other potential predictors like age of house head, education and land size. The table summarizes the descriptive statistics and analysis results. As can be seen each of the variables is positively and significantly correlated with the criterion, indicating that those with higher values on these variables tend to have higher amount of vegetable marketed.

\begin{tabular}{|l|c|c|c|c|}
\hline \multicolumn{1}{|c|}{ Variables } & $\begin{array}{c}\text { Regression } \\
\text { weight (B) }\end{array}$ & Std. error & T value & Sig. \\
\hline Intercept & -899.501 & 257.595 & -3.492 & .001 \\
\hline Education & 61.864 & 16.093 & $3.844^{* * *}$ & .000 \\
\hline Land size & 46.708 & 9.793 & $4.770^{* * *}$ & .000 \\
\hline Age & 12.764 & 4.918 & $2.596^{*}$ & .011 \\
\hline $\begin{array}{l}\mathrm{R}^{2}=.391, \mathrm{~F}(3,80) \\
=17.111^{* * *}\end{array}$ & & & & \\
\hline
\end{tabular}

Table 2: Summary of regression analysis.

$$
{ }^{*} \mathrm{p}<0.05{ }^{* *} \mathrm{p}<0.01 * * \mathrm{p}<0.001
$$

Source: Household Survey, 2016

The multiple regression model with all three predictors produced $\mathrm{R}^{2}=.391, \mathrm{~F}(3,80)=17.111, \mathrm{p}<.001$. For each one year increase in age, the amount of marketed vegetable will increase by $12.76 \mathrm{~kg}$, keeping others constant. Similarly, for each year increase in education, the amount for vegetable supply to market will increase by $61.86 \mathrm{~kg}$ and each ropani increase in land size will increase the vegetable marketed by $46.70 \mathrm{~kg}$, under ceteris paribas.

Based on this analysis, we can recommend that government and farmers should think to increase the education and land size to increase higher vegetable marketing.

Examinations of problems of vegetable production and marketing

All eighty three respondents were asked about the problems of vegetable production and marketing using five-level Likert scale. Later, these were ranked and tested by using Microsoft Excel and SPSS. The respondent ranked the problems giving the value 1 to 5 where 1 was given for most severe problem and 5 for no problem. The total value and the grade of each constraint were given in Table 3.
It was observed that lack of storage facility, inadequate government support and poor quality of inputs were found to be the major problems. As the study area was rural areas, there was lack of skilled manpower and agricultural technicians, so the storage facility was one of the most prominent problems having $98 \%$ of value. And lack of draft power was of least important problem.

\begin{tabular}{|l|c|c|}
\hline Problems & Total value & Grade \\
\hline Unavailability of inputs & 72 & XIII \\
\hline High inputs & 69 & XIV \\
\hline Poor quality of inputs & 73 & XII \\
\hline Labour shortage & 74 & XI \\
\hline High labour wage & 75 & X \\
\hline Poor market access & 93 & III \\
\hline Low price of outputs & 79 & VIII \\
\hline Lack of irrigation & 76 & IX \\
\hline Lack of storage facility & 98 & I \\
\hline Inadequate government support & 97 & II \\
\hline Lack of credit & 89 & V \\
\hline High interest rate of credit & 80 & VII \\
\hline Lack of draft power & 68 & XV \\
\hline Poor mechanization & 90 & IV \\
\hline Lack of modern technology & 88 & VI \\
\hline Poor transportation & 80 & VII \\
\hline
\end{tabular}

Table 3: Ranking of vegetable production problems.

Source: Household Survey, 2016

\section{Conclusion and Recommendation}

Among interviewed households, the average age of household head was 45 years. $90.48 \%$ were male headed and the rest $9.52 \%$ were female headed households in those VDCs. The average family size was found as 5.60. Similarly, the result showed that $35.71 \%$ of sampled household heads were illiterate and dependency ratio was found to be $58.06 \%$. Multiple regression analysis done to determine the predictors of market supply showed that age of households, education and land size was significantly determining the quantity of vegetable supplied to markets. One ropani ( 0.05 hactor) increase in land size tends to increase the vegetable supply by 36 kg keeping other variable constant. 
At farmer level, major problems were unavailability of inputs, high inputs price, poor quality of inputs, labour shortage, high labour wage, lack of irrigation, lack of credit, high interest rate of credit, poor mechanization and lack of modern technology. On marketing side poor market access, low price of outputs, lack of storage facility, lack of draft power poor transportation and inadequate government support were found. Some of the genuine problems related to production system such as diseases and pests severities, unavailability of good quality of seed and fertilizer in the input market hinder vegetable farmers from realizing optimum crop productivity. Likewise, marketing related problems such as poor market access, lack of transportation, low price of output and inadequate government support for price determination, poor availability of price information to farmers compared to traders contribute to market imperfectness. Both the types of problems are justified areas for policy makers, development actors and researchers to promote the production and marketing of vegetables in Sindupalchowk district. When the constraints, opportunities and farmer suggestions were studied keeping at same place, the working places for policy marker, development actors and researchers who show interest for promotion of production and marketing system were found.

These way forwards are discussed below

- The input supply system has to be improved so those farmers receive the right type of production inputs, quantity and quality needed at the right time. The role of researchers is to identify the high yielding varieties of vegetables. Local government, central government and donor agencies are strongly suggested to provide irrigation facility, fertilizers, pesticides and storage facility to those farmers.

- It is also highly recommended that the skill, knowledge and experience of farmers about package of practice (POP) ought to be upgraded. So, government should increase the role of extension system for scientific and technical support. This study suggests skill based training on production and marketing of vegetables.

- Production of vegetable is a risky business (because of its perishability) at times of over production causing prices to fall even below its harvesting or input costs. Promoting small scale processing plants that can add value to these products is one of the means to minimize risks.

\section{Bibliography}

1. Gurung B., et al. "Commercial vegetable farming: An approach for poverty reduction in Nepal". Agronomy Journal of Nepal 4 (2016): 92-106.

2. Rai MK., et al. "Vegetable Farming and Farmers' Livelihood: Insights from Kathmandu Valley, Nepal”. Sustainability 11.3 (2019): 889.

3. Regmi Khim Raj. Value chain analysis of vegetables in Palpa district of Nepal. Thesis. Vanaranashi: Institute of Agricultural Sciences, Banaras Hindu University, Varanasi, (2013).

4. HVAP. A report on value chain analysis of offseason vegetables (OSV). Surkhet: MOAD, High Value Agriculture Project (HVAP) in Hill and Mountain Areas, 2011.

5. Poudel Prabin. "Marketing margin assessment of offseason vegetables value chain in Serkhet Dailekh road corridor". The Journal of Agriculture and Environment 13 (2012): 27-31.

6. Pokhrel Deepak Mani. "Comparison of farm production and marketing cost and benefits". The Journal of Agriculture and Environment 11 (2010): 10-25.

7. Giziew A. "Determinants of market supply of vegetables: A case of AKAKI-KALITY SUB-CITY, Ethiopia". Journal of Rural Development 32.3 (2013): 281-290.

Volume 3 Issue 7 July 2019

(C) All rights are reserved by Manoj Sharma. 